\title{
Happiness: An interactionist perspective
}

\author{
Aaron Ahuvia - Neil Thin - Dan M. Haybron - Robert Biswas-Diener - Mathieu Ricard • \\ Jean Timsit
}

\begin{abstract}
Few would deny that happiness arises from a complex interaction of internal and external factors, like optimism on the one hand and money on the other. Yet research, as well as practical strategies for promoting happiness, tends to focus narrowly on one side or the other. A typical study, for instance, might examine the correlation between happiness and an internal variable like optimism, or an external variable like income. And practical strategies commonly divide into "change the world" versus "change your mind" approaches: promote health and wealth, for example, or cultivate gratitude for what you already have. This paper explores how our understanding of happiness is enhanced by "interactionist" approaches that emphasize the complex webs of interactions and feedbacks that give rise to happiness and unhappiness. While implicitly interactionist themes have increasingly characterized research on happiness, we anticipate that an explicit recognition of the interactionist perspective will foster greater attention to the complexities of happiness, particularly in the domain of human sociality, which involves especially rich and potent webs of interaction. A further upshot, we believe, is a greater awareness of our co-responsibility for one another's happiness.
\end{abstract}

Keywords: interactionism, internalism, externalism, happiness, policy, cognition, income, intervention

\section{Introduction}

When a person is experiencing a normal life difficulty such as a lack of enthusiasm for their job they might ask themselves questions like, "Should I change careers?" or "Should I try to rekindle my former enthusiasm for this work?" When an individual considers her aspirations or faces hardship it is common to consider whether it is preferable to invest in changing her circumstances or to invest in changing the way she feels about those circumstances. These strategies illustrate the contrast between two commonly advocated paths toward the good life: externalism (i.e. an emphasis on altering one's social or material circumstances) and internalism (i.e. an emphasis on altering one's beliefs, values, emotional responses, and similar psychological states). ${ }^{1}$ In this article we explicitly recognize the value of both internalist and externalist approaches, yet we advocate a more interactionist approach that recognizes the interactions and interdependencies between internal and external variables and seeks the right combination of mind and world.

\footnotetext{
${ }^{1}$ One of the authors has used these terms for a very different distinction regarding philosophical theories of wellbeing (Haybron, 2008), but we trust there is little risk of confusion. As well, we note that 'happiness' is used here as a psychological term, but we remain neutral among the different accounts of happiness in this sense (life satisfaction, hedonism, emotional state, etc.).
}

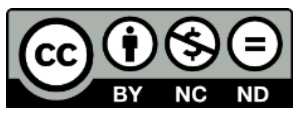


Understanding the interdependent relationships between external and internal influences on happiness is of clear relevance to theorists. It is also of crucial importance to government policy makers, clinical psychologists, coaches, and anyone else who aims to increase his or her own happiness or the happiness of others. In a companion piece to this paper (authors, in preparation), we explore the practical implications of an interactionist approach to happiness intervention. Here, we provide an interdisciplinary overview of the topic that integrates perspectives from anthropology and social planning, consumer research, neuroscience and religious studies, art and humanities, philosophy and psychology. We illustrate how an interactionist approach can serve as a lens that allows us to see how happiness emerges from, and is embedded in, a rich network of interactions, including internal and external factors. Interactionism encompasses two related views of what we might call felicitation - the causation and promotion of happiness (Helliwell, Weijers, Powdthavee, \& Jarden, 2011): explanatory interactionism attempts to explain the causal processes by which happiness arises, while strategic interactionism attempts to identify practical strategies for promoting happiness. We are concerned with both variants of the approach in this paper.

In this paper we provide a brief overview of internalist and externalist approaches to happiness. Our intention is not to treat these as straw men but to outline advantages and limitations associated with each. It is in regard to their respective limitations that we then offer a more in-depth discussion of interactionism. We do not present interactionism as an entirely novel or unique approach to felicitation; interactionist themes are familiar from other fields, as in the 'nature vs. nurture' debate, and have long appeared in discussions of happiness (e.g., Bishop, 2012; Fredrickson \& Joiner, 2002). Our aim, rather, is to encourage readers to avoid taking partisan positions with regard to happiness processes. We believe that interactionism is a more organic and naturalistic concept by which to describe happiness than are either internalism or externalism alone. It is our hope that an interactionist perspective can help to integrate disparate research programs and approaches to felicitation, fostering a greater understanding and appreciation of the complexities of happiness, and that, as a result, it will be useful to investigators, policy makers and interventionists.

\section{Unpacking internalism: Its benefits and limitations}

Internalism is the belief that happiness is produced largely by mental perception. Champions of internalism recognize that our experience of the world is constructed subjectively. This view is often acknowledged in psychological research on happiness. For example, Brannan and colleagues (2013) conducted a study that drew a distinction between social support and perceived social support. Similarly, Biswas-Diener and Diener (2001) make a distinction between objective income and income satisfaction. In light of subjective interpretation, internalists often argue that by intentionally changing our evaluations and perceptions we can effect real psychological change. This is particularly true of happiness. Proponents of internalism typically assert that happiness-enhancing mental strategies can be developed through practice.

Internalism's appeal can be seen in the idea that "changing one's mind" requires very few resources. For that reason, it is a happiness strategy that is available to people of all backgrounds. Further, internalism is appealing because it appears to be effective. It has been shown that attention (Brefczynski-Lewis, Lutz, Schaefer, Levinson, \& Davidson, 2007), compassion and emotional regulation (Lutz, McFarlin, Perlman, Salomons, \& Davidson, 2008) can be trained through meditation. Fredrickson, Cohn, Coffey, Pek, and Finkel (2008) have shown that loving-kindness meditation can enhance positive emotions and build consequential 
personal resources that contribute to wellbeing. Weng and others have shown that three weeks of compassion meditation, 30 minutes daily, promotes pro-social behavior and improves social relationships. The benefits of internalism are not limited to meditation techniques or Eastern philosophies. The entire enterprise of clinical psychology is founded, to some extent, on the belief that tolerating and regulating emotional and other internal experiences is possible by engaging in internal processes. Cognitive therapies, for instance, work by having people reflect upon their own interpretations of events and reframe them in more functional terms.

Despite its broad appeal there are legitimate criticisms of internalism. Some internalists over-emphasize the autonomy of the individual vis-à-vis social and ecological influences. They claim that individuals can develop the capacity to be less affected by adversities and deficits in their social and ecological environments but, as yet, we know relatively little about the limits of this mental control. Many self-help books claim to offer swift and easy ways to gain mastery over one's mind and to become independent from outer circumstances. Most of those claims turn to be short-lived and end up in disenchantment with the recommended methods (Bergsma, 2007; 2010). Studies have shown that internalist strategies can be effective but require fortitude and patience to master them (Lazar et al., 2005). Therefore, more information is needed to better understand differences in effectiveness between various internalist approaches as well as individual attributes that might be implicated in internalist success.

There is also an ethical question mark over internalism. Because of the heavy emphasis on developing more resilient internal capacities, it might be tempting to assume that unhappiness is the fault of the individual. People who are miserable, by this way of thinking, simply have not exerted the effort or made the choice to perceive their life in a more positive way. As well, it remains unclear where, exactly, lies the line between advocating changes in adverse circumstances and simply changing one's mind. Some critics argue that internalist approaches foster complacency. To counter such a charge, proponents of internalism argue that gaining the inner capacity to face both favorable and unfavorable circumstances is in no way tantamount to helpless resignation or to condoning injustice. Mastery over one's mind, according to these advocates, helps people avoid becoming a "slave twice": a slave of others and a slave of one's own mind. While people should endeavor tirelessly toward overcoming iniquity, oppression and neglect, and towards achieving outer freedom for oneself and others, it is also vital to gain inner freedom from afflictive mental states.

Importantly, most schools of internalism, including both Buddhism and cognitive therapies, reject the notion that improving outer conditions should be neglected, and encourage one to engage with determination in altruistic activities that can alleviate the suffering of the self and of others. Internalists point out, however, that no matter what outer conditions might be-good or bad-there are always ways to work with one's mind in order to experience them in a more optimal way. They also recognize that since one's control of outer conditions is often limited, and even one's own inner conditions require considerable training to master, cultivating mental skills is a major asset in achieving a sustained wellbeing (Ekman, Davidson, Ricard \& Wallace, 2005).

\section{Unpacking externalism: Its benefits and limitations}

Externalist approaches are based on the proposition that there is a relatively straightforward transmission of external conditions and events to internal happiness. We understand 'external conditions' broadly, to include such non-mental factors as other people, life events, and material objects. Externalism has hitherto operated in most cultures as the default mode for governments, businesses, and many social organizations that see their main role as that of 
raising 'living standards', i.e. material and social conditions. Hence we might call this sort of approach default externalism. A good example can be found in mainstream economics, which identifies wellbeing with the satisfaction of one's preferences. Since individuals are also assumed to be fully informed and rational, and their preferences fully revealed by their choices, the only way to promote wellbeing in this approach is through external conditions (Glaeser, 2011; Hausman \& McPherson, 2006). Hence, proponents of externalism have long favored attention to indicators of external living conditions like GDP and individual income.

For perfectly understandable reasons people have often tried to improve their own lives by rearranging living conditions rather than through mental self-discipline. Until recently, most humans suffered from unmet basic needs and their poor health and vulnerability to violence and premature death were the main threats to their happiness. Where food, safe living conditions, and other basic material conditions are in short supply it obviously makes sense to give them priority. It is reasonable to assume that reductions in illbeing will result from economic growth and from enhanced provision of medical services, infrastructure, schooling, and the rule of law. Externalism has therefore made very good sense throughout most of human evolution. In any case many external conditions are valuable to us in their own right. We don't need to justify health, peace, and environmental beauty by checking that they make us happy.

Still, even among the poor and distressed, pure externalism can be less effective than interactionist strategies that explore interactions between material provisioning, social transformation, and psychological resources. Even severely disadvantaged people such as the homeless have a variety of psychological strengths that can greatly enhance their prospects for personal or collective self-improvement (Tweed, Biswas-Diener, \& Lehman, 2012). Provision of enabling environments and resources is only one part of a complex route to the enhancement of less tangible goods such as long-term enjoyment, meaning, and life satisfaction. The flow of benefits from improvements in external living conditions has to work in synergy with people's psychological resources. Community development that enhances collective hope and pride will tend to work more effectively than top-down planning (Appadurai, 2002).

As with internalism, there are legitimate criticisms of externalist approaches to happiness. First, externalist approaches, by their very nature, can undervalue the very psychological processes that are, themselves, implicated in happiness. For example, externalist strategies often face problems such as hedonic adaptation, social comparison, poor affective forecasting, irrationality, and the costs of choice. Hedonic adaptation means that there are often diminishing returns to the removal of discomforts and to the provision of comforts (Shane \& Loewenstein, 1999). Social comparison means that if relevant other people improve their access to external goods, our own mental benefits from similar improvements may be diminished (Diener, Diener, \& Diener, 1995; Hirsch, 1977). Failures of affective forecasting mean that we want and strive for things that will either make us unhappy or will contribute less to our happiness than we imagine (Dunn \& Laham, 2006; Haybron, 2008; Wilson \& Gilbert, 2005). There are systematic misapprehensions in people's beliefs about the relations between wanting, liking, and learning (Berridge \& Kringelbach, 2013). Cognitive biases induce a variety of predictably irrational and otherwise suboptimal choices that can undermine the pursuit of our goals (Haybron 2008; Hsee, Zhang, Yu, \& Xi, 2003; Kahneman, 2011). Finally, simply having a large number of options can be costly, for instance leaving us less happy with what we do have (Schwartz, 2004).

A second criticism of externalist strategies toward happiness relates to the potential environmental downsides of the consumption of resources. Many social critics have 
highlighted ways in which the onward march towards external affluence has often resulted in unintended pathologies (Bennett, 2001; Freud, 1930/2002; Schor, 1998). Many kinds of external good are subject not only to diminishing returns, but also to toxic reversals, causing us to become paradoxically unhappy and unhealthy in response to the successful pursuit of external rewards. Collectively, certain pathologies of modernity have been loosely labeled 'affluenza': the toxicities of excessive materialism, comfort and hygiene (De Graaf, Wann \& Naylor, 2001/2005; Hamilton \& Denniss, 2005; James, 2007). Another example can be seen in increasingly efficient and diverse food distribution systems that can lead, in turn, to rising rates of obesity and poor nutritional choices. The relentless pursuit of sensory pleasures may end up in addiction. On a larger scale, the present emphasis on pursuing happiness through resourceintensive forms of consumption is plainly unsustainable, risking grave harms to humanity and the rest of life. More efficient means of promoting human wellbeing are clearly needed. Internalist strategies alone will not suffice to set the world on a path to sustainable happiness, but they can play a role in helping us to be more efficient in seeking happy lives (NDP Steering Committee and Secretariat, 2013).

\section{Interactionism: An introduction}

Both internalist and externalist approaches to felicitation have much to offer, and will continue to have an important place in happiness research and promotion. That said, we hope it is noncontroversial to assert that happiness does not arise solely as the product of internal processes just as it cannot be promoted solely through the consumption of external goods. Happiness, rather, is a complex, dynamic phenomenon that emerges from the interaction of internal and external factors. We need a more comprehensive and dynamic understanding of the manifold interactions that give rise to happiness.

An interactionist approach focuses on the way happiness emerges from the interaction of mind and world. A key element of interactionist strategies is to identify the internal and external factors that are most important for affecting change; with special attention paid to synergies that give rise to self-reinforcing loops, or "felicitation feedbacks." (See, for instance, the discussion of the similarly named "upward spirals" in Fredrickson \& Joiner, 2002.)

While a precise definition of interactionism is open for future debate and exploration, most definitions would likely include the idea that happiness is caused by the interaction of two or more events including internal and external ones. We take the value of an interactionist approach to lie mainly in drawing attention to the fact that interdependencies among variables are complex and dynamic. It might be helpful to list some of the more noteworthy features of interactionist approaches, which may be exhibited to varying degrees, and in some cases not at all. Roughly, we might say that an explanatory or practical strategy is interactionist to the extent that it acknowledges, regarding the causation or promotion of happiness:

1) Interdependence

2) Complexity

3) Dynamics

4) Feedbacks

5) Holism

6) Context-sensitivity

An interactionist perspective thus discourages simplistic readings of psychological research. For example, researchers tend to focus on averages when describing happiness-related phenomena. Such results are undoubtedly valuable but the emphasis on averages can obscure 
individual variation. For example, some research has resulted in findings regarding levels of happiness following the death of a spouse. Even when means and standard deviations are reported they conceal the individual interactions between a person's unique mental state and the death of her spouse. Researchers have attempted to remedy this by analyzing the interaction of variables, controlling study environments, and evaluating potential mediators and moderators. Even so, we advocate more case studies and qualitative level analyses as an adjunct to larger quantitative studies. This is especially of concern as the general public increasingly consumes happiness-related science. Many lay consumers lack the methodological sophistication to adequately understand research and qualitative information regarding interactionism might be helpful in this regard.

Another example of risky simplification is the common practice of assigning fixed proportions to the various determinants of happiness. For instance, an oft-cited pie chart attributes $50 \%$ of the between-person variation in happiness to genetic factors, $10 \%$ to external circumstances, and $40 \%$ to intentional effort (Lyubomirsky et al., 2005). This sort of schematic may be a useful heuristic for certain purposes but it can also be misleading. For example, observed phenotypes cannot generally be explained via some specific contribution of genes ('nature') and environment ('nurture'), because genes and environment interact, in ways that cannot be easily disentangled. Similar concerns apply to estimates of the contribution of other factors, like external circumstances, to happiness.

Interactionist approaches to felicitation are nothing new. In fact perhaps the most famous secular writer on felicitation, Aristotle, was an excellent example of interactionism. Aristotle regarded purely externalist approaches, like seeking the good life through wealth and honor, with outright contempt, while he regarded relatively internalist approaches like the Stoic view as implausible, saying that a person cannot lead a happy life on the rack. He argued instead that happiness is properly pursued through a lifetime of excellent activity: fully exercising one's capacities through worthwhile activities. This view has an internal component, virtue, but also recognizes the importance of external goods: you cannot exercise your capacities without some degree of material wealth, health, friends, and so forth. Indeed, it is difficult to characterize most activities, like playing a musical instrument, in anything other than interactionist terms. Aristotle's view is inherently dynamic, viewing happiness as inextricably linked with doing. And it is holistic and contextualized: for the most part, you do not follow simple rules, or a prescribed number of formulaic steps. Rather, you respond sensitively to the situation as a whole, in all its particularity. The view is holistic, too, in that the primary focus is a whole life: happiness, for Aristotle, is a matter of an entire life lived well.

\section{Examples of interactionism}

In this section we illustrate interactionist themes through examples spanning several domains generally considered to be important for happiness: values (religion), work (employment), material conditions (money), and relationships (caregiving). The examples are not meant to be particularly striking; they are merely illustrative, indicating that interactionism is not a radical new approach. More intricate examples, less apt for brief illustrations, will doubtless grow more prominent as our understanding of felicitation improves.

\subsection{Religion}

In a meta-analysis of research linking religion to happiness, Hackney and Sanders (2003) found consistent modest positive correlations between religion and life satisfaction. This finding held across both behavioral aspects of religion (e.g. church attendance) and psychological aspects 
(e.g. personal devotion). Interestingly, the psychological benefits of religiosity appear to be affected by an interaction of both internal and external factors. In a series of studies employing nearly half a million respondents conducted by Diener, Tay and Myers (2011) the researchers found that the happiness associated with religiosity is, in part, a function of the match between the individual and the larger culture in which they live. Specifically, religious individuals living in highly religious nations appear to enjoy substantially more positive emotions than their non-religious counterparts if they are living in a country with difficult life circumstances. In addition, the researchers found that people appear to be happier if they live in a nation in which aggregate societal religiosity matches their own. This is consistent with other research that suggests that person-culture match is important to happiness (Fulmer et al., 2010). In this case the researchers discovered that correlations between personality traits such as extroversion and happiness variables were amplified if a given trait was reflected in aggregate societal personality norms for that trait. Where intervention is concerned this indicates it is worth exploring the possibility that individuals can increase their happiness by finding a fit between their internal states and preferences and social interactions that validate these. For example, it may be more important than people realize to live in environments where the prevailing culture matches their own values. The example is interactionist in that it illustrates how the impact of external variables, like prevailing social mores, mediates the happiness impact of internal variables like religious belief.

\subsection{Employment}

Labor has commonly been understood as an involuntary hardship that is tolerated as a route to the provisioning of external goods. But meaningful employment is increasingly understood as a key source of happiness (Thin, 2012). Happiness research on unemployment has confirmed the stark facts about this pathology: the effects of unemployment are, in general, devastating and the costs go well beyond the effects of lost income to include anger, loss of self-esteem, damage to social relations, and loss of a meaningful life narrative (McKee-Ryan, Song, Wanberg, \& Kinicki, 2005). Externalist common sense demands that we do everything we can to minimize involuntary unemployment, yet there are few instances of nations succeeding at this over long periods. So we also need strategies for coping more effectively with this adversity. These need to be supported by research that goes beyond mere confirmation of the generally adverse effects, to explore the many interacting mental, social, and environmental factors that influence responses to unemployment as well as those related to employment.

Hopes for the development of better coping strategies are offered by research showing highly varied responses to unemployment even among people of very similar socio-economic backgrounds, ranging from psychosocial devastation to surprising forms of life enhancement depending on various psychological, social, and ecological factors (Havitz, Morden, \& Samdahl, 2004; Tay \& Kuykendall 2013, pp. 169-171). The way unemployed people think about this situation has crucial influence on its effects: survey research has shown that the adverse effects of unemployment among both the unemployed and the employed vary significantly according to the degree of importance individuals attach to the event (Dolan \& Powdthavee 2012; Tay \& Kuykendall, 2013).

For many unemployed people it is the psychosocial rather than financial effects that really bite, and it is here that we have considerable leeway for positive psychosocial interventions. Unemployed people wishing to optimize their responses to this situation have to seek optimal combinations in their efforts to redress this specific external fact (by finding another job); changing their outlook on the situation (by finding less depressing things to think about, or by 
revising priorities, say through voluntary simplification and slowdown); changing their activities (e.g. adopting new engaging and rewarding leisure activities or voluntary work); changing their social relationships (finding new social engagements to replace the loss of workplace friends); and changing their material circumstances by changing their behavior (e.g. altering consumption patterns to get by comfortably with less money) (Havitz, Morden, \& Samdahl, 2004; Knabe, Rätzel, Schöb, \& Weimann, 2010).

Understood through an externalist lens, jobs and unemployment are things that happen to us, causal factors largely beyond our control that influence our wellbeing. An interactionist approach, by contrast, recognizes that jobs and unemployment are not only external life circumstances but are also highly dynamic processes that achieve their influence via identities, roles, activities, relationships, experiences, and reinterpretations of experiences over time. Jobs and joblessness involve both mental and environmental processes; action as well as reflection; personal situations and relationships. Individuals can passively accept their jobs or their joblessness, or they can modify either situation to something more conducive to happiness. Active engagement either with a job or with joblessness modifies it into something very different than it first appeared, and this in turn influences our mental states, our capabilities, and our self-esteem or sense of purpose.

\subsection{Money}

Because money can provide a wide variety of benefits including pleasurable experiences, social status, education, medical care, and if needed, even highly skilled lawyers, a person's income can be used as a summary measure for many desirable external conditions. For people living in poverty, the data tell a rather straightforward externalist story in which increased income allows people to meet their basic needs, and thus dependably leads to increased happiness (Ahuvia, 2012).

Studies of non-poor populations, however, tell a much more interactionist story. Higher levels of income generally lead to higher levels of satisfaction with one's income, which in turn leads to higher overall life satisfaction. But while the connection between income satisfaction and overall life satisfaction is fairly strong (correlations around .40-.50; Ahuvia \& Friedman 1998), one's objective income has a weak connection to one's subjective level of income satisfaction (correlations around .10-.30, Diener \& Oishi, 2000; Fuentes \& Rojas, 2001). This is because when people place a high value on money and the things it can buy, they also tend to be dissatisfied with their income even if it is quite high (Burchardt, 2005; Kasser, 2002; Richins \& Rudmin, 1994; Ryan \& Dziurawiec, 2001; Sirgy, Lee, Larsen, \& Wright, 1998). Thus being financially satisfied results from an interaction between one's external circumstances and one's psychological disposition towards materialism. This interaction effect also works the other way round (although it is not logically necessary that it should). Materialism and other forms of high-income aspirations are associated with unhappiness (Kasser 2002; Sirgy, 1998; Stutzer \& Frey 2004). But this relationship is moderated by income, such that the less income one has the greater the negative impact of materialism on happiness (Barbera \& Gürhan-Canli, 1997; Nickerson, Schwarz, \& Diener, 2007).

A broader moral is that the effect of money on happiness depends on a wide range of factors: values and priorities (do people have materialistic priorities?), cultural norms (is conspicuous consumption discouraged?), social arrangements (do people need cars to get around?), and so forth. As well, material attainments can themselves affect people's outlooks, for instance reducing the ability of individuals to savor everyday experiences (Quoidbach, Dunn, Petrides, \& Mikolajczak, 2010), or impeding prosocial behavior, perhaps to their own 
(and certainly others') detriment (Piff, Stancato, Côté, Mendoza-Denton, \& Keltner, 2012). In short, the money-happiness connection is extremely complex, calling for an interactionist approach to explanation and practice.

\subsection{Caregiving}

Caregiving aims at improving the physical and mental situation of others in suffering. It turns out that the caregiver's attitude and state of mind greatly influence both her own capacities to take care of others, the quality of her care and the satisfaction of the person she is caring for.

Empathic resonance with someone else's feelings occurs with various positive mental states, such as joy, or negative ones such as suffering. Empathically resonating with the pain of others can lead to very different situations: experiencing empathic distress (Batson, 1991; Hoffman, 1981), distancing oneself emotionally from those that one is taking care of (Kash et al., 2000), or caring for them with loving-kindness without being overwhelmed by distress.

Dealing repeatedly with the pain of others often leads to emotional exhaustion. One study showed that, in the United States, $60 \%$ of caregivers suffer from burnout at one point in their career, and a third is affected to the point of having to pause their activities (Felton, 1998). This kind of burnout has also been called "compassion fatigue."

The overall level of nurses' burnout in hospital units also affects patients' satisfaction and their perception of the quality of care (Leiter, Harvie, \& Frizzell, 1998; Vahey, Aiken, Sloane, Clarke, \& Vargas, 2004). Patients who stayed on units where nursing staff felt more exhausted or more frequently expressed the intention to quit because of burnout were less satisfied with the various components of their care. Conversely, no significant correlations were found between nurse professional efficacy and any of the patient satisfaction components measured.

One does see here two kinds of interactions that can lead to either an upward or to a downward spiral for all concerned: if a caregiver cultivates loving-kindness through meditation, she will be protected against burnout. She will consequently be able to provide better care to her patients and those patients will acknowledge the benefits of such care. Caregivers will thus be encouraged to continue caring for others as they observe the two-fold benefit, for others and for themselves, of their activities. In contrast, when caregivers suffer from empathic distress, they cannot take good care of the patients and may end up quitting their job, while their patients experience a significant degradation in the provision of care.

Caregiving illustrates a particularly central area of concern for interactionism, human relationships, which involve especially dense webs of causal interactions and feedbacks. A marriage can easily get into a rut, for instance, where mutually reinforcing negative interactions - a raised eyebrow begets a contemptuous tone of voice, and so on - can leave the individuals feeling trapped in a vicious equilibrium. The same sort of dynamic can arise between troubled children and school officials, where misconduct and punishment can be mutually reinforcing. A key area of interest for promoting happiness is understanding better how to break relationships out of vicious cycles, particularly by learning how to exploit felicitation feedbacks that, ideally, result in upward spirals to much more rewarding relationships.

\subsection{Discussion}

These examples are meant to give some sense of the varieties and promise of interactionist approaches to felicitation, both in research and in practice. Given that the mechanisms involved in these cases are perfectly ordinary and widely implicated in human psychology we hope it is clear that many more such examples exist. Indeed, our intensely social nature should make it 
fairly clear that interactionist felicitation (the fostering of happiness in the self or in others) can occur in many settings. Now that we have some examples of interactionist felicitation in hand, it will be helpful to note three main types of interaction: psychosomatic, ecological, and psychosocial.

\section{Types of interactions}

\subsection{Mind-body ('psychosomatic') interactions}

Everyday activities ranging from participation in sport to sexual acts point to the importance of the body as an important tool in the happiness process. We hear a lot about psychosomatic illness but there is considerably less research and public awareness concerning the psychosomatic enhancement of psychological wellbeing. There is a growing body of research articulating the relationship between happiness and health (Cohen \& Pressman, 2006; Diener \& Chan 2011). Experiments show that we can deliberately engineer synergetic reactions between an inner desire to feel joyful and an outward pretense at smiling which gradually becomes a genuinely joyful smile as it causes mental changes. Strack, Martin and Lepper (1988), for example, conducted an experiment in which participants who held a pen in their teeth (forcing a fake smile) found cartoons funnier than those who held a pen between their lips (forcing a frown). Deliberate facial feedback loops modulate ongoing emotions and initiate desired emotions (McIntosh, 1996). We also know that meditators learn to modulate their experience of physical pain. When experienced meditators generate a mental state of "open presence" and are then subjected to intense pain they show almost no anticipatory distress at the approach of pain, increase their tolerance of it, and recover swiftly following the infliction of pain (Lutz, et al., 2013; Perlman, et al., 2010).

\subsection{Mind-Physical Environment (ecological)}

There is a growing body of research in environmental psychology demonstrating the importance of observing the natural environment. 'Attention restoration theory' has been developed and repeatedly used in studies exploring the psychological and health benefits of appealing views of nature (Bowler, Buyung-Ali, Knight, \& Pullin, 2010; Kaplan, 1995; Lambin \& Fagan, 2012). Even apparently insignificant modification of surroundings can have measurable effects: In Taiwan experimenters put six plants at the back of a classroom out of the children's normal line of vision and found significant improvements in various psychological and social factors such as sense of comfort and friendliness compared to the control group, plus significantly fewer hours of sick leave and recorded instances of misbehavior (Han, 2009).

Importantly, these impacts are not simply "outside-in" influences on happiness (you see a tree and it makes you happy). Rather, natural environments trigger a wide range of psychological impacts that, among other things, alter our cognitive and affective dispositionseffectively changing our programming, at least temporarily (Haybron, 2011; 2014). Researchers have noted a wide range of attitudinal changes, such as a decline in materialistic values and increase in concern for others, in people exposed to natural environments. In one study of people living in public housing, those assigned to "gray" apartments with no view of vegetation fared worse on a wide array of outcomes than those living in "green" apartments. For instance, gray apartment dwellers experienced more domestic violence, felt less connectedness with neighbors and had worse coping skills and self-discipline (e.g., Kuo \& Sullivan, 2001). The quality of our physical environment not only affects our happiness; it also 
affects the way we respond to things, including our ability to gain happiness from other things in our lives.

There is more work to be done exploring the complexities of causal interactions between the environments that people engage with, their states of mind and motivations, and the relevance of social interactions to the causal patterns. For example, urban planners can learn a great deal about the often puzzling diversity in psychological responses to the built environment by observing collective interactions affecting perception of some spaces but not others as convivial and safe. Planners are increasingly aware that place-making is not a simple matter of providing specific environmental goods and expecting them to deliver psychosocial wellbeing: interpretation of responses requires complex qualitative observation and analysis of interactions between cultural history, social structures, and behaviors over time (Shaftoe, 2008).

\subsection{Mind-Culture/Society}

Among the most subtle and powerful interactions are those that occur between the individual and society. Cultural contexts and scripts influence our emotional experiences and selfevaluations including those representing the well-lived life, and the disapproval of specific kinds of hardwired desires and gratifications. Interestingly, personal choice and behavior have a reciprocal influence such that individuals, in turn, also impact the change of societal norms over time.

Cultural influences are sometimes overlooked as internal-external interactions because they are often experienced as if they were happening only within the mind. People frequently view their own values and choices as completely internal phenomena without adequate appreciation of the powerful influences of external cultural processes. For example, Oishi and Diener (2003) found that people from different cultures remembered events-especially those related to personal performance-along cultural lines and that these memories, in turn, affected their subsequent choices. Specifically, people from Asian cultures mis-remembered their actual performance on a problem-solving task as being lower than it actually was while their European-American counterparts inflated performance in their memories. The culturally determined memories, and not actual performance, influenced their desire to engage in a similar activity when given a choice.

In recent decades, our resources for understanding both cultural and ecological interactions have been greatly augmented by research on situational influence. Through many studies we have learned how extraordinarily sensitive human beings are to subtle influences from the social and physical environment. For example, people's willingness to help someone may be strongly influenced by whether they just found a dime, whether a lawnmower is running nearby, or whether they are alone or in a crowd (for a review, see Ross \& Nisbett, 1991). More disturbing are experiments finding it remarkably easy to get participants to administer painful and possibly fatal shocks to a stranger (Milgram, 1963), or to descend rapidly into sadistic torment having simply been asked to pretend to be prison guards (Zimbardo, Haney, Banks, \& Jaffe 1973). More recently, much attention has been garnered by research on "nudges," where small environmental changes induce important changes in behavior - for instance, saving for retirement because the default option on the paperwork was changed (Thaler \& Sunstein, 2008). Studies of social contagion suggest that many behaviors and outcomes, including obesity, smoking, happiness, unhappiness, and divorce, ripple through social networks like a virus (Christakis \& Fowler, 2012). Other research, on biculturals, migrants, and sojourners, finds profound effects on personality variables as individuals move from one cultural context to another (Heine \& Lehman, 2004; LaFromboise, Coleman, \& Gerton, 1993). Situational 
influences of these sorts tend to be unconscious and automatic, leaving us largely unaware of their operation. To a surprising extent, our behavior and states of mind are shaped by the social and physical environment (Haybron, 2014). The fact that we are so little aware of such influences may be a major reason interactionist approaches to felicitation have not been more prominent: we may underestimate how thoroughly interdependent our minds and actions are with those around us, and even our physical surrounds. More than we might have realized, our pursuit of happiness depends very much on those around us, and theirs on ours.

\section{Co-responsibility}

One of the most important results of adopting an interactionist view of happiness is the ability to better address the question of "whose responsibility is happiness?" This question might seem radical in that many people would default to a seemingly obvious answer that it is the individual who is responsible for her own happiness. Indeed, more extreme internalist positions would hold that the individual has final authority over subjective happiness. Externalists, by contrast, might be more willing to concede the role of outside actors in providing events and opportunities that influence happiness. Even here, however, we believe that externalists would largely believe that the individual is responsible for her own happiness, even if that only means that she is responsible for acquiring and consuming those resources which will likely make her happy.

We suggest that it is neither realistic nor ethical to try to persuade individuals that they are solely responsible for their own happiness; nor should any individual, in whatever social or professional capacity, feel that they can absolve themselves of their responsibility for other people's happiness. Co-responsibility - the idea that happiness emerges as a collective and cooperative endeavor that requires both favorable life conditions and individual effort - is an important argument justifying the use of an interactionist lens in policy and practice at all levels from families to business to governments.

At first glance, the idea of co-responsibility may seem puzzling, since one core idea of happiness, especially in the West, is the idea of taking a 'first person' perspective on motivations and self-evaluations such that individuals are the ultimate experiencers of their own internal states. In fact, the entire field of psychology is primarily concerned with internal states and happiness is no exception (Kashdan, Biswas-Diener \& King, 2008). This is why psychologists and self-help professions have been developing visions and strategies for selfimprovement that place a core emphasis on autonomous efforts to transform the mind. It is also, perhaps, for this reason that government policymakers have been slow to warm to the notion that happiness-enhancing programs are appropriate to the workplace or in public programs. On deeper inspection, happiness is often interactively constructed via social and ecological engagements. We all influence other people's happiness: directly and explicitly by helping one another to develop and sustainably pursue good life goals; through teaching and acting as role models, and less directly through more general emotional contagion, empathic resonance and imitation, and through our influences on shared environments (Helliwell et al., 2011).

The moral basis for claims about co-responsibility, we note, is not particularly tendentious: probably most moral philosophers recognize some imperative of co-responsibility for happiness. Utilitarians, for instance, enjoin us to count a stranger's happiness as no less important than our own, while Kantians maintain that we have duties of beneficence: we must to some extent promote the happiness of others, as befits the recognition of their equal worth as persons. An interactionist lens puts a less familiar spin on such imperatives, emphasizing the 
interdependence of happiness among persons. As the caregiving example illustrates, caring for others is not an entirely distinct project from self-care.

\section{Conclusion}

We have tried in this paper to provide a basic framework for addressing the fundamental process of happiness by focusing on a single foundational question: what factors give rise to happiness? Scholarly debate on this issue has centered on two categories of causality: external circumstances and internal psychological processing of experience. We argue here that happiness emerges from the interaction of inner and outer conditions. External conditions provide potentials for happiness and internal processes act as filters for real world experience. These two processes mutually affect each other.

As often happens with young sciences, explanation naturally begins with highly simplified models, and over time adds greater complexity; to some extent, an increasing tendency toward interactionist analysis may be a standard feature of scientific inquiry itself. With regards to happiness, specifically, we believe that this process is especially true. Because happiness is a topic with enormous public appeal scholars and practitioners alike have devoted attention to it. Interventionists, especially, are likely to simplify tools, skills and models of happiness because they are easier to teach, learn and implement. It may be, for this reason, that nuance, dynamic interactions and similar complicating factors are often side-stepped. We argue that the time has arrived for scholars and practitioners to focus more heavily on contextual and interactionist processes relating to happiness.

The art of optimizing those interactions is far from simple, and calls for greater attention to the dynamics of happiness. Fortunately, we see such attention being given to happiness in a growing range of individual, business, and societal policies and interventions. Indeed, increasing numbers of city, state and national governments are looking at happiness as a topic worthy of both measurement and intervention. Similarly, organizations are increasingly focusing on meaning, strengths, and a positive culture as an important element of modern work life.

Among our most dearly held points in this article is the idea of co-responsibility. Once a person acknowledges that happiness does not simply arise out of positive personal perceptions and attitudes the door opens to mutual responsibility for individual happiness. It is here, we believe, that the interactionist perspective has the most powerful implications. In the context of co-responsibility happiness is not a "self-help" pursuit but is, rather, a collective enterprise.

\section{Acknowledgments}

The authors wish to acknowledge the Franco American Cultural Trust for their generous support of Project+

\section{Authors}

Aaron Ahuvia

University of Michigan

aaronahuvia@gmail.com

Neil Thin

University of Edinburgh

Dan M. Haybron 


\section{St. Louis University}

Robert Biswas-Diener

Portland State University

Mathieu Ricard

Shechen Monastery

Mind and Life Institute

Jean Timsit

HEC Paris ( Ecole des hautes etudes commerciales), Project +

\section{Publishing Timeline}

Received 15 July 2014

Accepted 1 December 2014

Published 26 January 2015

\section{References}

Ahuvia, A. C. (2012). Wealth, consumption and happiness. In A. Lewis (Ed.), The Cambridge Handbook of Psychology and Economic Behaviour (pp. 199-206). Cambridge, England: Cambridge University Press.

Ahuvia, A. C., \& Friedman, D. C. (1998). Income, consumption, and subjective well-being: Toward a composite macromarketing model. Journal of Macromarketing, 18(2), 153. http://dx.doi.org/10.1177/027614679801800207

Appadurai, A. (2002). The capacity to aspire: Culture and the terms of recognition. In V. Rao, and M. Walton (Eds.), Culture and public action: How cultural factors affect an unequal world (pp. 59-84). Washington, DC: World Bank.

Barbera, P. L., \& Gürhan-Canli, Z. (1997). The role of materialism, religiosity, and demographics in subjective well-being. Psychology \& Marketing, 14, 71-97. http://dx.doi.org/10.1002/(SICI)15206793(199701)14:1<71::AID-MAR5>3.0.CO;2-L

Batson, C. D. (1991). The altruism question: Toward a social-psychological answer. Hillsdale, NJ: Erlbaum.

Bennett, O. (2001). Cultural pessimism: Narratives of decline in the postmodern world. Edinburgh: Edinburgh University Press

Bergsma, A. (2007). Do self-help books help? Journal of Happiness Studies, 9(3), 341-360. http://dx.doi.org/10.1007/s10902-006-9041-2

Bergsma, A. (2010). The state of the art in happiness advice; Can we escape the dodo-verdict? Journal of Happiness Studies, 11(5), 649-654. http://dx.doi.org/10.1007/s10902-010-9200-3

Berridge, K. C., \& Kringelbach, M. L. (2013). Towards a neuroscience of well-being: Implications of insights from pleasure research. In H. Brockmann and J. Delhey (Eds.), Human happiness and the pursuit of maximization (pp. 81-100). Dordrecht: Springer.

Bishop, M. (2012). The network theory of well-being: An introduction. The Baltic International Yearbook of Cognition, Logic and Communication, 7, 1-29. http://dx.doi.org/10.4148/biyclc.v7i0.1773

Biswas-Diener, R., \& Diener, E. (2001). Making the best of a bad situation: Satisfaction in the slums of Calcutta. Social Indicators Research, 55, 329-352. http://dx.doi.org/10.1023/A:1010905029386

Bowler, D. E., Buyung-Ali, L. M., Knight, T. M., \& Pullin, A. S. (2010). A systematic review of evidence for the added benefits to health of exposure to natural environments. BMC Public Health, 10(1), 1-10. http://dx.doi.org/10.1186/1471-2458-10-456

Brannan, D., Biswas-Diener, R., Mohr, C., Mortazavi, S., \& Stein, N. (2013). Friends and family: A crosscultural investigation of social support and subjective well-being among college students. Journal of Positive Psychology, 8, 65-75. http://dx.doi.org/10.1080/17439760.2012.743573 
Brefczynski-Lewis, J. A., Lutz, A., Schaefer, H. S., Levinson, D. B., \& Davidson, R. J. (2007). Neural correlates of attentional expertise in long-term meditation practitioners. Proceedings of the National Academy of Sciences, 104, 11483-11488. http://dx.doi.org/10.1073/pnas.0606552104

Burchardt, T. (2005). Are one man's rags another man's riches? Identifying adaptive expectations using panel data. Social Indicators Research, 74(1), 57-102. http://dx.doi.org/10.1007/s11205-005-6519-y

Christakis, N. A., \& Fowler, J. H. (2012). Social contagion theory: Examining dynamic social networks and human behavior. Statistics in Medicine, 32, 556-577. http://dx.doi.org/10.1002/sim.5408

Cohen, S., \& Pressman, S. D. (2006). Positive affect and health. Current Directions in Psychological Science, 15, 122-125. http://dx.doi.org/10.1111/j.0963-7214.2006.00420.x

De Graaf, J., Wann, D., \& Naylor, T. H. (2001/2005). Affluenza: The all-consuming epidemic (2nd ed.). San Fransisco: Berrett-Koehler

Diener, E., \& Chan, M. Y. (2011). Happy people live longer: Subjective well-being contributes to health and longevity. Applied Psychology: Health and Well-Being, 3(1), 1-43. http://dx.doi.org/10.1111/j.1758$\underline{0854.2010 .01045 . x}$

Diener, E., Diener, M., \& Diener, C. (1995). Factors predicting the subjective well-being of nations. Journal of Personality and Social Psychology, 69(5), 851-864. http://dx.doi.org/10.1037/0022-3514.69.5.851

Diener, E., \& Oishi, S. (2000). Money and happiness: Income and subjective well-being across nations. In E. Diener \& E. M. Suh (Eds.), Culture and subjective well-being. Cambridge, Massachusetts: MIT Press.

Diener, E., Tay, L., \& Myers, D. G. (2011). The religion paradox: If religion makes people happy, why are so many dropping out? Journal of Personality and Social Psychology, 101, 1278-1290. http://dx.doi.org/10.1037/a0024402

Dolan, P., \& Powdthavee, N. (2012). Thinking about it: A note on attention and well-being losses from unemployment, Applied Economics Letters, 19 (4), 325-328. http://dx.doi.org/10.1080/13504851.2011.577000

Dunn, E. W., \& Laham, S. A. (2006). A user's guide to emotional time travel: Progress on key issues in affective forecasting. In J. Forgas (Ed.), Hearts and minds: Affective influences on social cognition and behavior. New York: Psychology Press

Ekman, P., Davidson, R. J., Ricard, M., \& Wallace, B. A. (2005). Buddhist and psychological perspectives on emotions and well-being. Current Directions in Psychological Science, 14(2), 59-63. http://dx.doi.org/10.1111/j.0963-7214.2005.00335.x

Felton, J. S. (1998). Burnout as a clinical entity-its importance in health care workers. Occupational Medicine, 48 , 237-250. http://dx.doi.org/10.1093/occmed/48.4.237

Fredrickson, B. L., \& Joiner, T. (2002). Positive emotions trigger upward spirals toward emotional wellbeing. Psychological Science, 13, 172-175. http://dx.doi.org/10.1111/1467-9280.00431

Fredrickson, B. L., Cohn, M. A., Coffey, K. A., Pek, J., \& Finkel, S. M. (2008). Open hearts build lives: Positive emotions, induced through loving-kindness meditation, build consequential personal resources. Journal of Personality and Social Psychology, 95, 1045-1062. http://dx.doi.org/10.1037/a0013262

Freud, S. (1930/2002). Civilization and its discontents. London: Penguin

Fuentes, N., \& Rojas, M. (2001). Economic theory and subjective well-being: Mexico. Social Indicators Research, 53(3), 289-314. http://dx.doi.org/10.1023/A:1007189429153

Fulmer, C. A., Gelfand, M. J., Kruglanski, A. W., Prieto, C., Diener, E., Pierro, A., \& Higgins, E. T. (2010). On "feeling right" in cultural contexts: How person-culture match affects self-esteem and subjective well-being. Psychological Science, 21, 1563-1569.

http://dx.doi.org/10.1177/0956797610384742

Glaeser, E. L. (2011). The moral heart of economics. The New York Times.

Hackney, C.H. \& Sanders, G. S. (2003). Religiosity and mental health: A meta-analysis of recent studies. Journal for the Scientific Study of Religion, 42, 43-55. http://dx.doi.org/10.1111/1468-5906.t01-1-00160

Hamilton, C., \& Denniss, R. (2005). Affluenza: When too much is never enough. Crows Nest, NSW: Allen \& Unwin. 
Han, K. T. (2009). Influence of limitedly visible leafy indoor plants on the psychology, behavior, and health of students at a Junior High School in Taiwan. Environment and Behavior, 41(5), 658-692. http://dx.doi.org/10.1177/0013916508314476

Hausman, D. M., \& McPherson, M. S. (2006). Economic analysis, moral philosophy, and public policy. New York: Cambridge University Press. http://dx.doi.org/10.1017/CBO9780511754289

Havitz, M. E., Morden, P. A., \& Samdahl, D. M. (2004). The diverse worlds of unemployed adults: Consequences for leisure, lifestyle, and well-being. Waterloo, ON: Wilfrid Laurier University Press.

Haybron, D. M. (2008). The pursuit of unhappiness: The elusive psychology of well-being. New York: Oxford University Press.

Haybron, D. M. (2011). Central Park: Nature, context, and human wellbeing. International Journal of Wellbeing, 1, 235-254. http://dx.doi.org/10.5502/ijw.v1i2.6

Haybron, D. M. (2014). Adventures in assisted living: Well-being and situationist psychology. In N. E. Snow \& F. V. Trivigno (Eds.), The philosophy and psychology of character and happiness (pp. 241-265). New York: Routledge.

Heine, S. J., \& Lehman, D. R. (2004). Move the body, change the self: Acculturative effects on the selfconcept. Psychological Foundations of Culture, 305-331.

Helliwell, J. F., Weijers, D., Powdthavee, N., \& Jarden, A. (2011). Felicitators. International Journal of Wellbeing, 1, 193-306. http://dx.doi.org/10.5502/ijw.v1i2.1

Hoffman, M. L. (1981). Is altruism part of human nature? Journal of Personality and Social Psychology, 40, 121-137. http://dx.doi.org/10.1037/0022-3514.40.1.121

Hirsch, F. (1977). Social limits to growth. London: Routledge

Hsee, C. K., Zhang, J., Yu, J., \& Xi, Y. (2003). Lay rationalism and inconsistency between predicted experience and decision. Journal of Behavioral Decision Making, 16, 257-272. http://dx.doi.org/10.1002/bdm.445

James, O. (2007) Affluenza. London: Vermilion

Kahneman, D. (2011). Thinking, fast and slow. New York: Farrar, Straus and Giroux.

Kaplan, S. (1995). The restorative benefits of nature: Toward an integrative framework. Journal of Environmental Psychology, 15(3), 169-182. http://dx.doi.org/10.1016/0272-4944(95)90001-2

Kash, K. M., Holland, J. C., Breitbart, W., Berenson, S., Dougherty, J., Ouelllette-Kobasa, S., \& Lesko, L. (2000). Stress and burnout in oncology. Oncology, 14(11), 1621-1629, 1633.

Kashdan, T., Biswas-Diener, R., \& King, L. (2008). Reconsidering happiness: the costs of distinguishing between hedonics and eudaimonia. The Journal of Positive Psychology, 3(4), 219-233. http://dx.doi.org/10.1080/17439760802303044

Kasser, T. (2002). The high price of materialism. Cambridge, Massachusetts: MIT Press.

Knabe, A., Rätzel, S., Schöb, R., \& Weimann, J. (2010). Dissatisfied with life but having a good day: Timeuse and well-being of the unemployed. The Economic Journal, 120(547), 867-889. http://dx.doi.org/10.1111/i.1468-0297.2009.02347.x

Kuo, F., \& Sullivan, W. (2001). Aggression and violence in the inner city. Environment and Behavior, 33(4), 543-571. http://dx.doi.org/10.1177/00139160121973124

LaFromboise, T., Coleman, H. L., \& Gerton, J. (1993). Psychological impact of biculturalism: evidence and theory. Psychological Bulletin, 114, 395. http://dx.doi.org/10.1037/0033-2909.114.3.395

Lambin, E., \& Fagan, T. L. (2012). An ecology of happiness. Chicago, IL: University of Chicago Press. http://dx.doi.org/10.7208/chicago/9780226466699.001.0001

Leiberg, S., Klimecki, O. M., \& Singer T. (2011). Short-term compassion training increases prosocial behavior in a newly developed prosocial game. PLoS ONE, 6(3), e17798. http://dx.doi.org/10.1371/journal.pone.0017798

Leiter, M. P., Harvie, P., \& Frizzell, C. (1998). The correspondence of patient satisfaction and nurse burnout. Social Science E Medicine, 47, 1611-1617. http://dx.doi.org/10.1016/S0277-9536(98)00207-X

Lutz, A., Brefczynski-Lewis, J. A., Johnston, T., \& Davidson R. J. (2008). Voluntary regulation of the neural circuitry of emotion by compassion meditation: Effects of expertise. PLoS ONE, 3(3), e1897. 
Lutz A., McFarlin, D., Perlman, D. M., Salomons, V. \& Davidson, R. J. (2013). Altered anterior insula activation during anticipation and experience of painful stimuli in expert meditators. Neuroimage, 64, 538-546. http://dx.doi.org/10.1016/j.neuroimage.2012.09.030

Lyubomirsky, S., Sheldon, K. M., \& Schkade, D. (2005). Pursuing happiness: The architecture of sustainable change. Review of General Psychology, 9, 111-131. http://dx.doi.org/10.1037/1089$\underline{\text { 2680.9.2.111 }}$

McIntosh, D. N. (1996). Facial feedback hypotheses: Evidence, implications, and directions. Motivation and Emotion, 20(2), 121-147. http://dx.doi.org/10.1007/BF02253868

McKee-Ryan, F., Song, Z., Wanberg, C. R., \& Kinicki, A. J. (2005). Psychological and physical well-being during unemployment: A meta-analytic study. Journal of Applied Psychology, 90(1), 53-76. http://dx.doi.org/10.1037/0021-9010.90.1.53

Milgram, S. (1963). Behavioral study of obedience. The Journal of Abnormal and Social Psychology, 67(4), 371-378. http://dx.doi.org/10.1037/h0040525

NDP Steering Committee and Secretariat. (2013). Happiness: Towards a new development paradigm. Report of the Kingdom of Bhutan.

Nickerson, C., Schwarz, N., \& Diener, E. (2007). Financial aspirations, financial success, and overall life satisfaction: Who? And how? Journal of Happiness Studies, 8(4), 467-515. http://dx.doi.org/10.1007/s10902-006-9026-1

Oishi, S., \& Diener, E. (2003). Culture and well-being: The cycle of action, evaluation, and decision. Personality and Social Psychology Bulletin, 29, 939-949. http://dx.doi.org/10.1177/0146167203252802

Perlman, D. M., Salomons, T.V., Davidson R. J., \& Lutz, A. (2010). Differential effects on pain intensity and unpleasantness of two meditation practices. Emotion, 10, 65-71. http://dx.doi.org/10.1037/a0018440

Piff, P. K., Stancato, D. M., Côté, S., Mendoza-Denton, R., \& Keltner, D. (2012). Higher social class predicts increased unethical behavior. Proceedings of the National Academy of Sciences. http://dx.doi.org/10.1073/pnas.1118373109

Quoidbach, J., Dunn, E. W., Petrides, K. V., \& Mikolajczak, M. (2010). Money giveth, money taketh away: The dual effect of wealth on happiness. Psychological Science, 21(6), 759-763. http://dx.doi.org/10.1177/0956797610371963

Richins, M. L., \& Rudmin, F. W. (1994). Materialism and economic psychology. Journal of Economic Psychology, 15(2), 217-231. http://dx.doi.org/10.1016/0167-4870(94)90001-9

Ross, L., \& Nisbett, R. E. (1991). The Person and the situation: Perspectives of social psychology. Philadelphia: Temple University Press.

Ryan, L., \& Dziurawiec, S. (2001). Materialism and its relationship to life satisfaction. Social Indicators Research, 55(2), 185-197. http://dx.doi.org/10.1023/A:1011002123169

Schor, J. (1998). The overspent American. New York: Harper Perennial.

Schwartz, B. (2004). The paradox of choice. New York: Harper Collins.

Shaftoe, H. (2008). Convivial urban spaces. New York: Routledge.

Sirgy, J. (1998), Materialism and the quality of life. Social Indicators Research, 43, 227-260. http://dx.doi.org/10.1023/A:1006820429653

Sirgy, J. M., Lee, D. J., Larsen, V., \& Wright, N. (1998). Satisfaction with material possessions and general well-being: The role of materialism. Journal of Consumer Satisfaction/Dissatisfaction and Complaining Behavior, 11, 103-118.

Strack, F., Martin, L. L., \& Lepper, S. (1988). Inhibiting and facilitating conditions of the human smile: A nonobtrusive test of the facial feedback hypothesis. Journal of Personality and Social Psychology, 54(5), 768. http://dx.doi.org/10.1037/0022-3514.54.5.768

Stutzer, A., \& Frey, B. (2004). Reported subjective well-being: A challenge for economic theory and economic policy. Journal of Applied Science, 124, 191-231.

Tay, L., \& Kuykendall, L. (2013). Promoting happiness: The malleability of individual and societal subjective wellbeing. International Journal of Psychology, 48(3), 159-176.

http://dx.doi.org/10.1080/00207594.2013.779379 
Thaler, R. H., \& Sunstein, C. R. (2008). Nudge: Improving decisions about health, wealth, and happiness. Princeton, NJ: Yale University Press.

Thin, N. (2012). Social happiness: Research into policy and practice. Bristol: Policy Press.

Tweed, R. G., Biswas-Diener, R. \& Lehman, D. R. (2012). Self-perceived strengths among people who are homeless. Journal of Positive Psychology, 7(6), 481-492. http://dx.doi.org/10.1080/17439760.2012.719923

Vahey, D., Aiken, L., Sloane, D., Clarke, S., \& Vargas, D. (2004). Nurse burnout and patient satisfaction. Medical Care, 42(2), II-57-66.

Wilson, T. D., \& Gilbert, D. T. (2005). Affective forecasting: Knowing what to want. Current Directions in Psychological Science, 14(3), 131-134. http://dx.doi.org/10.1111/j.0963-7214.2005.00355.x

Zimbardo, P. G., Haney, C., Banks, W. C., \& Jaffe, D. (1973). The mind is a formidable jailer: A Pirandellian prison. The New York Times Magazine, 8, 38-60. 